\title{
RECENT DECISIONS AFFECTING THE DEVELOPMENT OF THE MARCELLUS SHALE IN PENNSYLVANIA
}

\author{
Kevin C. Abbott ${ }^{*}$ and Nicolle R. Snyder Bagnell**
}

Pennsylvania has a long history of natural gas exploration and development beginning in the 1800's. Despite having some of the country's oldest jurisprudence dealing with oil and gas disputes, Pennsylvania case law regarding oil and gas operations is relatively undeveloped in comparison to states like Texas and Oklahoma. With the boom in leasing and developing in the region in the last few years, there has also been an increase in oil and gas litigation in Pennsylvania state and federal courts. This paper will discuss the recent decisions that have impacted the development of Marcellus law in Pennsylvania, as well as identify some of the significant pending issues that are worth watching.

\section{LEASE DISPUTES}

\section{A. The Minimum Royalty Act and Its Interpretation}

Perhaps the single most important case decided in the last three years related to oil and gas development in Pennsylvania is the Pennsylvania Supreme Court's decision in Kilmer v. Elexco Land Services, Inc., ${ }^{1}$ which analyzed Pennsylvania's Minimum Royalty Act. ${ }^{2}$ The Kilmer case was one of over seventy lawsuits filed in state and federal court in Pennsylvania regarding whether existing oil and gas leases should be voided for failure to comply with the Act. $^{3}$

Specifically, the challenges were to what costs could be deducted from the proceeds of the gas prior to the payment of a royalty to the lessor. ${ }^{4}$ It is generally accepted that the lessee/producer bears all of the costs of production

\footnotetext{
* Kevin Abbott is a partner in the Energy and Natural Resources Group at Reed Smith with more than thirty years of experience representing oil and gas clients in Appalachia.

** Nicolle Snyder Bagnell is a partner and leader of the Oil and Gas Team of the Energy and Natural Resources Group at Reed Smith.

1. 990 A.2d 1147 (Pa. 2010).

2. $\quad 58$ P.S. $\S 33(1979)$.

3. 990 A.2d at 1151 .

4. See id.
} 
of natural gas. ${ }^{5}$ Those costs may include everything from initial preparation of the well site, drilling and casing, and fracturing, to restoration. These costs are significant, especially for horizontal wells designed to produce gas from the Marcellus Shale formation. As a result, the lessee/producer bears not only all of the costs of drilling a well, but also all of the risk that the well will not produce or be profitable. ${ }^{6}$

If a well produces, that production occurs at the wellhead. From there, it is transported to points of sale downstream. Although the gas theoretically could be sold at the wellhead, typically it is not. In between the well head and the point of sale numerous activities may be undertaken to make the gas saleable, or saleable at a higher price, and those activities have costs. These potential costs include: the cost to process or dehydrate the gas, the cost to compress and transport the gas, and costs to market and sell the gas. ${ }^{7}$

In other states, how these costs are treated for purposes of calculating royalties varies. However, two distinct approaches have developed: the "at the well" rule, which generally permits the deduction of post-production costs after the gas reaches the wellhead, and the "marketable product" approach, which generally does not permit deduction of post-production costs until the gas is in "marketable condition." "Despite the fact that there are two general approaches, the application of these approaches varies significantly between the jurisdictions. The most extreme approach to date has been adopted in West Virginia. One West Virginia court held that no post-production costs may be deducted from the wellhead to the point of sale, unless such costs and the methods for calculating those costs are explicitly stated in the lease. ${ }^{9}$ Until recently, there was, essentially, no Pennsylvania royalty litigation, but Pennsylvania did have legislation governing royalties.

5. See, e.g., Howard R. Williams \& Charles J. Meyers, Manual of Oil and Gas Terms § R (Patrick H. Martin \& Bruce M. Kramer eds., 2009) (defining "royalty" as "the landowner's share of production, free of expenses of production").

6. See Kilmer v. Elexco Land Servs., Inc., 990 A.2d 1147, 1156 (Pa. 2010).

7. Id. at 1157 .

8. See, e.g., id. $\S \S 645-645.2$; Brian S. Wheeler, Deducting Post-Production Costs When Calculating Royalty: What Does the Lease Provide?, 8 Appalachian J.L. 1 (2008); Edward B. Poitevent, II, Post-Production Deductions From Royalty, 44 S. Tex. L. Rev. 790 (2003).

9. See Estate of Tawney v. Columbia Natural Res., L.L.C., 633 S.E.2d 22 (W. Va. 2006). 


\title{
1. Pennsylvania Minimum Royalty Act
}

In 1979, the Pennsylvania legislature passed the Minimum Royalty Act (the Act) ${ }^{10}$ which states:

\begin{abstract}
A lease or other such agreement conveying the right to remove or recover oil, natural gas or gas of any other designation from lessor to lessee shall not be valid if such lease does not guarantee the lessor at least one-eighth royalty of all oil, natural gas or gas of other designations removed or recovered from the subject real property. ${ }^{11}$ An oil, natural gas or other designation gas well or oil, natural gas or other designation gas lease which does not provide a one-eighth metered royalty shall be subject to such an escalation when its original state is altered by new drilling, deeper drilling, redrilling, artificial well stimulation, hydraulic fracturing or any other procedure for increased production. A lease shall not be affected when the well is altered through routine maintenance or cleaning. ${ }^{12}$

Whenever such an increased production procedure has been completed prior to the effective date of this act, metering and the above royalty shall commence within 90 days after the effective date of this act. ${ }^{13}$
\end{abstract}

From 1979 until recently, the Act was seldom addressed. In fact, there was only one published opinion concerning the Act, a Pennsylvania Supreme Court decision in 1992 that held that the statute could not be applied retroactively so as to reform a pre-Act flat-rate lease to provide for a oneeighth royalty. ${ }^{14} \mathrm{~A}$ "flat-rate" lease is a lease that provides for a stated annual royalty, e.g. \$200 per year. Flat-rate leases are not tied to the volume of the oil or gas produced. Prior to the Act, flat-rate leases were common. After the Act was passed in 1979, the majority of leases provided for a royalty of one-eighth of production and many allowed for the deduction of certain expenses incurred after production.

Beginning in 2008, roughly 30 years after its enactment, the Act garnered significant attention. As was noted above, over 70 different lawsuits, involving hundreds of leases, were filed in state and federal courts in

10. Today, this Act goes by many names. In Kilmer v. Elexco Land Servs., Inc., 990 A.2d 1147 (Pa. 2010), it was referred to as the Guaranteed Minimum Royalty Act ("GMRA"). In reality, when the Act was passed in 1979 it was not named and it was not accompanied by any legislative history or discussion. See generally 58 Pa. StAт. ANN. § 33 (West 1996) ("An Act regulating the terms and conditions of certain leases regarding natural gas and oil.").

11. 58 Pa. Stat. AnN. $\S 33$ (West 2006).

12. Id. $\$ 34$

13. Id. $\S 35$.

14. See Kepple v. Fairman Drilling Co., 615 A.2d 1298, 1304 (Pa. 1992). 
Pennsylvania. ${ }^{15}$ Although the claims in each case were different, the main issue in all of the cases was the royalty owners' contention that any lease clause that explicitly or implicitly permits the deduction of post-production costs in the calculation of a royalty violates the Act and, as a result, rendered the lease void because the Act requires a guarantee of a minimum royalty of one-eighth. ${ }^{16}$ The lessors argued that they were entitled to one-eighth of the proceeds of the gas without sharing in any of the costs of getting the gas to market. ${ }^{17}$

In some of the early cases, the lessees sought to compel arbitration pursuant to arbitration clauses in the leases that required the arbitration of all disputes arising under the leases. In response, the royalty owners' argued that the arbitration provisions did not apply because the leases containing the arbitration provisions were void. ${ }^{18}$ Despite that argument, arbitration was compelled in some of the cases. ${ }^{19}$ In other early cases, federal judges refused to consider the claims, invoking their discretionary power to decline to hear a declaratory judgment claim because the dispute involved a declaration of the meaning of a state statute that was never interpreted by the state courts. ${ }^{20}$

A few cases did address the issue on the merits. In two cases decided by the same federal judge, the court denied the producer's motion to dismiss the royalty owners' claims in language that, while dicta, favored the plaintiffs' claim that the deductions lessened their royalty. ${ }^{21}$ In one case, the court analyzed the following lease provision:

Lessee ... shall pay the Lessor on gas, including casing head gas and other gaseous substances, produced and sold from the premises one-eighth (1/8th) of the amount realized from the sale of gas at the well (meaning the amount realized less all costs of gathering, transportation, compression, fuel, line loss and other post-production expenses incurred downstream of the wellhead). ${ }^{22}$

\footnotetext{
15. See Kilmer v. Elexco Land Servs., Inc., 990 A.2d 1147, 1151 (Pa. 2010).

16. Id. at $1151-53$.

17. Id. at $1154-56$.

18. Id.

19. See, e.g., Ulmer v. Chesapeake Appalachia, L.L.C., No. 4:08-CV-2062, 2009 U.S. Dist. LEXIS 124650 (M.D. Pa. Jan. 16, 2009).

20. See, e.g., Belcher v. The Keeton Group, No. 3:09-CV-506 (May 8, 2009).

21. See Stone v. Elexco Land Servs., Inc., No. 3:09-CV-264, 2009 U.S. Dist. LEXIS 45897 (M.D. Pa. June 1, 2009); Kropa v. Cabot Oil \& Gas Corp., 609 F. Supp. 2d 372 (M.D. Pa. 2009).

22. Kropa, 609 F. Supp. 2d at 379; Kropa v. Cabot Oil \& Gas Corp., No. 3:08-CV-551, slip op. (M.D. Pa. July 26, 2010) (memorandum and order denying plaintiff's motion for reconsideration).
} 
The court stated that "[a]lthough the lease technically does provide for a guaranteed one-eighth royalty, it then proceeds to explain that costs will be deducted from that amount. The royalty then becomes less than one-eighth and a violation of the plain language of the statute. ${ }^{23}$ The federal court, however, did not deny the motions to dismiss on that basis. ${ }^{24}$ Instead, the court found that the term "royalty" was ambiguous because some jurisdictions permitted the deduction of post-production expenses while others, relying on the implied covenant of marketability, did not allow such deductions unless they were expressly agreed to in the lease. ${ }^{25}$ Because the court found the term "royalty" to be ambiguous, it denied the motion to dismiss. ${ }^{26}$

\title{
2. The Kilmer Lease
}

The first claim to make its way to the Pennsylvania Supreme Court was the Kilmer case. ${ }^{27}$ That case involved whether a lease with the following royalty provision violated the Act:

\begin{abstract}
Lessor shall receive as its royalty one eighth (1/8th) of the sales proceeds, actually received by Lessee from the sale of such production, less this same percentage share of all Post Production Costs, as defined below, and this same percentage share of all production, severance and ad valorem taxes. As used in this provision, Post Production Costs shall mean (i) all losses of produced volumes (whether by use as fuel, line loss, flaring, venting or otherwise) and (ii) all costs actually incurred by Lessee from and after the wellhead to the point of sale, including, without limitation, all gathering, dehydration, compression, treatment, processing, marketing and transportation costs incurred in connection with the sale of such production. ${ }^{28}$
\end{abstract}

The Kilmer case had an interesting, and relatively rare, journey through the court system. The case was initially heard in Pennsylvania's Court of Common Pleas, the trial court level. There, trial court granted the producer's motion for summary judgment. ${ }^{29}$ The lessors immediately appealed the decision to the Pennsylvania Superior Court. The lessee, however, asked the Pennsylvania Supreme Court to bypass the Superior Court by exercising its extraordinary jurisdiction and hearing the appeal. ${ }^{30}$ The lessees were

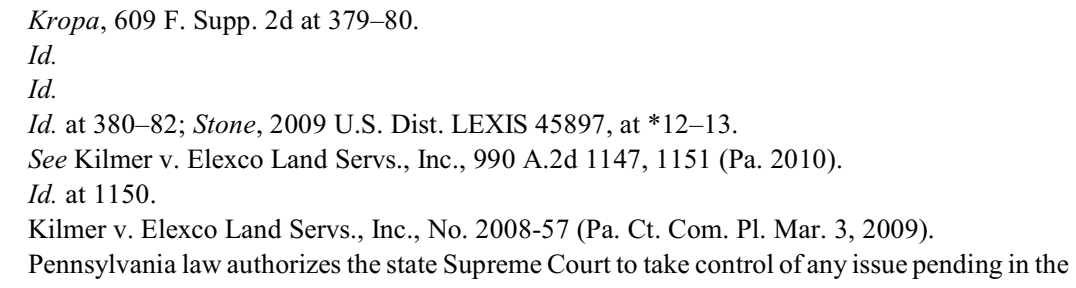


supported by the state's largest oil and gas trade associations. Together they argued that with so many pending cases in state and federal courts, there was a risk of inconsistent interpretations of the Act. ${ }^{31}$ Because the meaning of the Act could impact the validity of thousands of leases, the Court's interpretation was critical to the state's oil and gas industry. The Pennsylvania Supreme Court exercised its jurisdiction and certified the following issue for immediate appeal: "whether the [Guaranteed Minimum Royalty Act] precludes parties from contracting to use the net-back method to determine the royalties payable under an oil or natural gas lease." 32

\section{The Kilmer Decision}

On March 24, 2010, the Pennsylvania Supreme Court, in a unanimous opinion, held that a producer may deduct post-production costs in calculation of the minimum royalty required by the Act. ${ }^{33}$ The Kilmer court focused on the provision of the Act that requires that oil and gas leases must guarantee the lessor "at least one-eighth royalty of all oil, natural gas or gas of other designations removed or recovered from the subject real property." 34 As in the other pending cases, the primary dispute between the lessors and the lessee was whether post-production costs that were incurred to process the gas and get it to the point of sale could be deducted from the proceeds of the sale of the gas prior to calculating the royalty. ${ }^{35}$ The lessors contended that such costs had to be incurred solely by the producers and that the Act required a oneeighth royalty of the gross proceeds of sale. ${ }^{36}$ The producers argued that the royalty was properly calculated as a share of the value of the gas at the wellhead, not the ultimate point of sale. ${ }^{37}$ The producers argued that postproduction costs incurred must be deducted from the proceeds of sale before the one-eighth royalty was calculated, because the post-production activities, such as processing and transportation, increased the value of the gas as it

\footnotetext{
lower courts when it deems a need to address an issue of immediate public importance. 42 PA. Cons. STAT. ANN. $§ 726$ (West 2004).

31. Reply Brief In Support of Petition for Extraordinary Jurisdiction Pursuant to 42 PA. Cons. STAT. ANN. § 726 at 2-3; Kilmer v. Elexco Land Servs., Inc., 990 A.2d 1147 (Pa. 2010) (No. 46 MM 2009).

32. Kilmer, 990 A.2d at 1151.

33. See id. at 1158 .

34. Id. at 1156 .

35. See id.

36. See id. at 1151-52.

37. Id. at 1154 .
} 
moved from the wellhead to the point of sale. ${ }^{38}$ This method of calculating a royalty is known as the "net-back" method. ${ }^{39}$

The Pennsylvania Supreme Court sided with the producers and held that the Act "should be read to permit the calculation of royalties at the wellhead, as provided by the net-back method. ..." adopted the definition of "royalty" that allows deduction of post-production costs. $^{41}$

Because of the Kilmer court's decision, it remains unsettled whether a lease that is found to be "invalid" under the Act is in fact void. Furthermore, there is no language in the Act or the legislative history that indicates the legislature intended to void leases; rather than, reform them to be "valid."

\section{The Aftermath of Kilmer}

After the Kilmer decision, not all of the pending claims disappeared. Plaintiffs have continued to prosecute their claims under the Act by seeking to distinguish their leases from the one analyzed in Kilmer. The District Court for the Middle District of Pennsylvania decided several of these cases and, in each case, rejected claims seeking to distinguish specific leases from Kilmer. ${ }^{42}$

38. Id. at $1154-56$.

39. See id. at 1149 n.3.

40. Id. at 1158 .

41. Id. at $1157-58$ (" $[\mathrm{w}]$ hile a lease may make the amount of the royalty dependent on the proceeds, generally the royalty is not payable from gross profit but from the net amount remaining after deduction of certain production and development costs." (citing 17 WiLLISTON ON CONTRACTS § 50:60 (4th ed. 2009)).

42. See Kropa v. Cabot Oil \& Gas Co., 716 F. Supp. 2d 375, 378 (M.D. Pa. 2009); Hayes v. Chesapeake Appalachia, L.L.C., No. 3:09-CV-619 (M.D. Pa. Aug. 27, 2010); Lauchle v. The Keeton Group L.L.C., No. 4:08-CV-1868 (M.D. Pa. Oct. 6, 2010); Beach v. MK Resource Partners II, L.P., No. 4:08-CV-1950 (M.D. Pa. Oct. 6, 2010); Hooker v. The Keeton Group LLC, et al., No. 4:08-CV-2091 (M.D. Pa. Oct. 6, 2010); Rodriguez v. Chesapeake Appalachia, L.L.C., No. 3:08-CV-2068, 2010 U.S. Dist. LEXIS 127188 (M.D. Pa. Dec. 1, 2010). 
In an opinion analyzing three of the post-Kilmer claims, the federal court reviewed the leases' royalty provisions ${ }^{43}$ and explained that Kilmer was meant to be read broadly, stating:

Though the essence of Plaintiff's argument is that Kilmer's holding should be narrowly applied, it is our view that Kilmer is properly read broadly in light of the fact that the Pennsylvania Supreme Court granted extraordinary jurisdiction to resolve the purely legal question of whether post-production costs are proper under Pennsylvania oil and gas law. The Pennsylvania Supreme Court recognized the more than seventy lawsuits, including the instant matters, pending in the Pennsylvania State and Federal Courts and the potential for stymied economic development when deciding to grant extraordinary jurisdiction to resolve this legal issue once and for all. Applying common sense to the matter, it is evident that the Pennsylvania Supreme Court surely considered that all of the leases that would be affected by their decision were not identical, thus their holding cannot be strictly applied only to leases that are on all fours to the lease in Kilmer. Such an application of Kilmer, or, rather, a non-application of Kilmer, defies both common sense and the concept of precedent. $^{445}$

43. The royalty provision as it appears in the Lauchle and Hooker cases provides the following: (B.) ROYALTY: It is agreed that the total Royalty that will be paid by Lessee shall be one eighth (1/8th) and that any Royalty conveyance or reservation in Lessor's chain of title shall be subtracted from the one eighth (1/8th) royalty provided herein. To pay lessor as Royalty, less all taxes, assessments, and adjustments on production from the Leasehold as follows:

$* * *$

2. GAS: To pay Lessor an amount equal to one-eighth of the revenue realized by the Lessee for all gas and the constituents thereof produced and marketed from the Leasehold during the preceding month. Lessee may withhold Royalty payment until such time as the total withheld exceeds fifty dollars $(\$ 50.00)$.

Lauchle v. The Keeton Group LLC, No. 4:08-CV-1868 (M.D. Pa. Oct. 6, 2010); Hooker v. The Keeton Group LLC, No. 4:08-CV-2091 (M.D. Pa. Oct. 6, 2010). The royalty provision in the Beach case contains the following terms:

(B.) ROYALTY: To pay Lessor as Royalty, less all taxes, assessments, and adjustments and other permitted deductions on production from the Leasehold as follows:

$* * *$

2. GAS: To pay Lessor an amount equal to one-eighth of the revenue realized by the Lessee for all gas and the constituents thereof produced and marketed from the Leasehold during the preceding month.

It is agreed that the total Royalty that will be paid by Lessee shall be one-eighth $(1 / 8$ th) and that any Royalty conveyance or reservation in Lessor's chain of title shall be subtracted from the one-eighth $(1 / 8$ th) royalty provided herein. Lessee may withhold Royalty payment until such time as the total withheld exceeds fifty dollars (\$50.00). "Revenue realized" shall mean the price received by Lessee for all oil, gas and constituents thereof produced and marketed from the Leasehold less any charges for transportation, dehydration, compression, and marketing paid by Lessee to deliver the oil, gas and constituents for sale.

Beach v. MK Resource Partners II, L.P., No. 4:08-CV-1950 (M.D. Pa. Oct. 6, 2010).

44. See Carey v. New Penn Exploration, LLC, 2010 U.S. Dist. LEXIS 52199 (M.D. Pa. Apr. 28, 2010) (Caputo, J.) (upholding a lease agreement that provided landowners with a one-eighth royalty after deduction of post-production expenses incurred downstream of the wellhead); Puza v. Elexco Land Services, Inc., 2010 U.S. Dist. LEXIS 43346 (M.D. Pa. May 3, 2010) (Caputo, J.) (same); Julia v. Elexco 
In addition to the federal opinions, one state court has followed the federal courts' lead and applied Kilmer broadly, even where the lease did not explicitly spell out what deductions were permitted.

\section{Royalty Claims}

Although Kilmer resolved how to apply the Act, it did not address the issue of what costs may be deducted under a specific lease, especially if the lease simply provides for a calculation "at the well" or "at the wellhead." The Kilmer court noted that it was not faced with that issue, inasmuch as the lease at issue in Kilmer explicitly delineated the post-production costs to be deducted. ${ }^{46}$

Unsurprisingly, the second theory being tested by lessors concerns how deductions were taken. To date, these claims have involved class actions which seek declaratory relief and damages due to the lessors' claims that certain deductions, especially those involving volumetric deductions and affiliate transactions, were not permitted or were improperly calculated. One of those cases has already been settled, ${ }^{47}$ while others remain pending. ${ }^{48}$

Land Services, Inc., 2010 U.S. Dist. LEXIS 45821 (M.D. Pa. May 11, 2010) (Caputo, J.) (same); Kropa v. Cabot Oil and Gas Corporation, 2010 U.S. Dist. LEXIS 56647 (M.D. Pa. June 9, 2010) (Munley, J.) (same).

45. We cannot imagine that the Pennsylvania Supreme Court, after granting expedited consideration and jurisdiction, meant to render a holding so narrow as to invite its consideration of myriad other cases involving leases that were not entirely identical to the Kilmer lease. We empathize with Plaintiffs' desire to escape what they consider to be bad bargains. But they have put too fine a point on Kilmer in aid of voiding their leases. Both the Pennsylvania Supreme Court, and this Court, recognize the need for finality. A holding contrary to the one we render today would trigger havoc in a multi-billion dollar industry. More importantly, it would be in error.

It is our considered view that the Kilmer Court did not make their holding so narrow as to only apply to the lease at issue in Kilmer. Thus, we find, despite Plaintiffs' protestations to the contrary, that it is precisely not the holding of Kilmer that post-production costs must be divided into one-eighths born by the Lessor and seven-eights born by the Lessee for the lease to be valid. Nor do the post-production deductions provided for in the leases need to be identical to the Kilmer deductions to be valid. The holding of Kilmer is that the GMRA permits the calculation of the royalties at the wellhead utilizing the net-back method. That is exactly what the leases here provide, and as a result, we decline to void them.

Lauchle, No. 4:08-CV-1868; Beach, No. 4:08-CV-1950; Hooker, No. 4:08-CV-2091, Slip op.

at 10-11 (M.D. Pa. Oct. 6, 2010).

46. See Kilmer, 990 A.2d 1147.

47. Frederick et al. v. Range Res. et al., No. 1:08-CV-00288 (W.D. Pa. Oct. 13, 2010).

48. Pollack v. Energy Corp. of America, No. 2:10-CV-1553 (W.D. Pa. Nov. 22, 2010); Hall v. Consol Gas Co., GD 10-021633 (Pa. Ct. Com. Pl. Nov. 19, 2010); Christofel v. Atlas Energy, Inc., GD 10-011904 (Pa. Ct. Com. Pl. June 22, 2010). 
In Pollock v. Energy Corp. of America, a class action was filed alleging that Energy Corp. took impermissible volumetric deductions in calculating the lessors' gas royalties, used the incorrect price of gas sold when calculating the lessors' gas royalties, took improper deductions when calculating the lessors' gas royalties and either failed to, or insufficiently paid, the lessors' oil royalties. ${ }^{49}$ After an extensive discussion of the Kilmer case, the court noted that Energy Corp. advocated for an "expansive reading of Kilmer," applying the net-back method to all oil and gas leases, "regardless of whether a lease describes the particulars of the post-production costs that can be deducted from the gross sales price." because the leases at issue, unlike those dissected in Kilmer, do not specifically provide for a deduction for lost gas from the royalty, [Energy Corp.] breached the leases when it did not pay royalties on that category of gas." ${ }^{51}$ The court, however, citing a prior federal decision, rejected the plaintiffs" "narrow" reading of Kilmer. ${ }^{52}$ The court further went on to hold that because all of the leases at issue utilized the net-back method of royalty calculation, "[g]as that does not make it to [its] destination . . cannot be considered in the calculation." ${ }^{, 53}$ Thus, Plaintiffs' claims regarding gas lost or unaccounted for prior to sale were foreclosed by Kilmer. ${ }^{54}$

The extension of leases due to claims made by landowners under the MRA is another issue that Pennsylvania courts have recently addressed. In Lauchle v. Keeton Group LLC, defendant's counterclaim argued that when the plaintiffs had sought declaratory judgments invalidating their leases under the MRA, plaintiffs had repudiated those leases. ${ }^{55}$ As such, defendant moved the court to equitably extend the terms of the plaintiffs' leases, after the court had already held that plaintiffs' leases were, in fact, valid under the MRA. ${ }^{56}$ The court, noting that this exact issue had not yet decided by Pennsylvania state courts, relied on a similar Pennsylvania Superior Court case to determine that W.D. Pa.)

\footnotetext{
50. Id. at $* 4$.

51. $I d$.

52. Id. at *4-*5 (citing Ulmer v. Chesapeake Appalachia, LLC, No. 4:09-CV-2062, 2011 WL permissible use of the net-back method under the GRMA").

53. $I d$. at $* 5$.

54. Id.

55. Lauchle v. Keeton Group LLC, 768 F. Supp. 2d 757, 759 (M.D. Pa. 2011).

56. Id. at 758-59.
} 1344596 (M.D. Pa. April 8, 2011) (refusing plaintiff's argument that the Kilmer decision did not apply due to variances between the Kilmer lease and the lease at issue, and stating that "Kilmer was not meant to be read narrowly" and therefore "the deduction of post-production costs contained in the lease . . is a 
plaintiffs had not, in fact, repudiated their leases simply by filing for declaratory judgments regarding their status under the MRA. ${ }^{57}$ As such, the court also refused to equitably extend the terms of those leases. ${ }^{58}$

\section{LEASING RIGHTS ISSUES}

In addition to claims by royalty owners, increased litigation over who owns the rights to the exploration and development of the Marcellus Shale and whether any lease ever existed or was terminated resulted from the development of Marcellus Shale.

\section{A. Lease Formation Claims}

A number of cases have dealt with the issue of contract formation. In several federal cases, whether the landowners' signing of the lease agreement constituted an offer or an acceptance was the central issue before the court. ${ }^{59}$

One such case is Lyco Better Homes, where the landowner signed leases that contained a provision stating that the agreement was subject to management and title approval. ${ }^{60}$ Months later, the producer sent a letter to the landowner stating that the leases were not approved by senior management, and thus were void. ${ }^{61}$ The landowner sued for breach of contract. The producer responded by arguing that the landowner's signing of the lease was merely an offer, which the producer could accept or reject, and that no contract was ever formed. ${ }^{62}$ Thus, the producer claimed proper use of its right to terminate the lease negotiations. ${ }^{63}$ The court agreed that the lease was unenforceable, holding that the producer "could have accepted or rejected the offers ... [and that the producer] communicated a rejection of the offers by returning the documents to [the landowners] marked with the "void' stamp."

57. Id. at 762 (citing Derrickheim Company v. Brown, 451 A. 2d 477 (Pa. Super. Ct. 1982)).

58. Id.

59. Hollingsworth v. Range Res.-Appalachia, L.L.C., No. 3:09-CV-838, 2009 U.S. Dist. LEXIS 100354 (M.D. Pa. Oct. 28, 2009); Lyco Better Homes, Inc. v. Range Res.-Appalachia L.L.C., No. 4:09-CV-00249, 2009 U.S. Dist. LEXIS 110425 (M.D. Pa. May 21, 2009). Another case with similar facts, Pigeon Creek Presbyterian Church v. Range Res.-Appalachia, L.L.C., No. 09-1399, 2010 U.S. Dist. LEXIS 3706 (W.D. Pa. Jan. 19, 2010), was recently stayed by the District Court for the Western District of Pennsylvania until the Third Circuit Court of Appeals renders its judgment in the Hollingsworth appeal.

60. See Lyco, 2009 U.S. Dist. LEXIS 110425.

61. Id. at $* 5$.

62. See id.

63. Id.

64. Id. at *7-8. 
The court also determined that the lease did not meet the requirements imposed by the statute of frauds because "[a]lthough [the landowners] contend that [the producer] informed plaintiffs of the lease approval via a telephone call ... in Pennsylvania, leases which will exceed three years must be in writing in order to be enforceable." 65

In Hollingsworth, a case with similar facts, the court dismissed the landowner's claim on grounds that "[n]o contract could be formed absent [the producer's] manifestation of an intent to be bound." 66 There, the court determined that the producer's preparation of the lease agreement did not amount to an offer because:

[a] ... manifestation of willingness to enter into a bargain is not an offer if the person to whom it is addressed [the landowner] knows or has reason to know that the person making it does not intend to conclude a bargain until he has made a further manifestation of assent [i.e., communicating management and title approval] ${ }^{67}$

The court ultimately held that the landowners claim failed because "they have alleged no further facts indicating an unconditional promise" by the producers since the producer's entrance into the agreement was "conditioned ... upon management review."68

A different result was reached in a third similar case, in which the landowners alleged a breach of contract action against the producer for its failure to pay them royalty and bonus payments. ${ }^{69}$ In Valentino, the landowners contended that they chose to sign a lease with the producer after they were offered a large bonus payment of $\$ 485,800.00$, despite being approached by various other producers to negotiate a lease. ${ }^{70}$ They argued that they were to receive the payment unless the producer surrendered the lease within ninety days. ${ }^{71}$ After the ninety days had elapsed, the landowners contacted the producer and the producer responded via letter that the lease had not been approved by its management and was not binding on either party. ${ }^{72}$ In response to the claim filed by the landowners, the producer filed a motion

65. Id. at *8 (citing Blumer v. Dorfman, 289 A.2d 463, 466 (Pa. 1972)).

66. Hollingsworth v. Range Res.-Appalachia, LLC, No. 3:09-CV-838, 2009 U.S. Dist. LEXIS 100354, at *9 (M.D. Pa. Oct. 26, 2009).

67. Id. (citing Restatement (SECOND) OF Contracts $§ 26$ (1979)).

68. Hollingsworth, 2009 U.S. Dist. LEXIS 100354, at*9.

69. Valentino v. Range Res.-Appalachia, LLC, No. 09-1615, 2010 WL 2034550, at*5 (W.D. Pa. May 21, 2010).

70. Id. at $* 1$.

71. Id. at $* 2-3$.

72. $I d$. 
to dismiss, arguing that the federal district court had granted motions to dismiss in both the Lyco and Hollingsworth cases, which were factually analogous. ${ }^{73}$ In response, the court held that it was not bound by the decision of another district court and that it could freely reconsider the issues ${ }^{74}$ and denied the motion to dismiss, holding that the landowners' allegations were sufficient to plead a breach of contract case. ${ }^{75}$

Another common claim raised by lessors seeking to void their leases was one for fraudulent inducement. Fraudulent inducement occurs when one party makes false representations which induce the other party to contract. ${ }^{76}$ To prove fraudulent inducement, the plaintiff must show: "(1) a false representation; (2) materiality; (3) scienter; (4) justifiable reliance; and (5) damage as a proximate result." ${ }^{177}$ Because claims of fraudulent inducement generally involve conversations that took place prior to the agreement, the parol evidence rule is often a factor. The parol evidence rule "bars evidence of previous oral or written negotiations or agreements involving the same subject matter as the contract . . . to explain or vary the terms of the contract." ${ }^{, 78}$ Two 2010 cases, however, held that the parol evidence rule is inapplicable to fraudulent inducement cases because the plaintiff offers the evidence of prior conversations not to explain or vary the terms of the contract, but to allege that the fraud prevented the contract from ever being formed. ${ }^{79}$ However, another judge in the Middle District of Pennsylvania held that " $[w]$ ith respect to fraudulent inducement, representations made prior to the contract are considered superseded and disclaimed by a fully integrated written agreement." 80

In addition to these seemingly conflicting rulings, the Middle District of Pennsylvania also held that "the question of whether claims of fraudulent inducement based on misrepresentation not related to subjects specifically addressed in the written contract are barred by the parol evidence rule" has not

73. Id. at $* 5$.

74. Id.

75. Id. at $* 7$.

76. Julia v. Elexco Land Servs., Inc., No. 3:09-CV-590, 2010 U.S. Dist. LEXIS 45821, at *8 (M.D. Pa. May 11, 2010).

77. $I d$. 2010).

78. Carey v. New Penn Exploration, L.L.C., 2010 U.S. Dist. LEXIS 52199, at *7 (M.D. Pa. Apr. 28,

79. Kropa v. Cabot Oil \& Gas Corp., 716 F. Supp. 2d 375 (M.D. Pa. 2010); Rodriguez v. Anadarko E\&P Co., Nos. 3:08-CV-2068, 3:08-CV-2069, 2010 WL 4962825 (M.D. Pa. Dec. 1, 2010).

80. Carey, 2010 U.S. Dist. LEXIS 52199, at*7. 
yet been resolved in the Pennsylvania state courts. ${ }^{81}$ Finally, two Middle District cases each granted a motion to dismiss where Plaintiff did not meet the scienter requirement of fraudulent inducement by failing to allege that defendant or their agents knew statements made were false, or recklessly disregarded the truth in making those statements. ${ }^{82}$

Recently, in Butler v. Charles Powers Estate, the defendants requested a declaratory judgment that a mineral reservation included Marcellus shale gas. ${ }^{83}$ The Superior Court of Pennsylvania, in considering an appeal of an order on preliminary objections, began its analysis by citing Pennsylvania precedent over 100 years old regarding the definition of the term "mineral." 84 Although that ancient precedent stated that " $[\mathrm{t}] \mathrm{he}$ cardinal test of the meaning of any word in any particular case is the intent of the parties using it," also stated that the term, "presumably is intended in the ordinary popular sense which it bears among English speaking people." ${ }^{, 66}$ However, when used in the context of land conveyances, the term "may include any inorganic substance found in nature having sufficient value separated from its situs as part of the earth to be mined, quarried, or dug for its own sake or its own specific uses." ${ }^{\circ 7}$ The Butler court, nonetheless, cited multiple Pennsylvania cases finding that the word "minerals" does not include natural gas or oil. ${ }^{88}$ Despite this compilation of case law, the Superior Court of Pennsylvania reversed and remanded the trial court's decision that the reservation of minerals did not include Marcellus shale gas. ${ }^{89}$ The court reasoned that further analysis was necessary as to whether Marcellus shale was a "mineral," whether Marcellus shale gas is the same kind of natural gas contemplated in the prior case law, and whether Marcellus shale is similar to coal in that the owner of the Shale is also the owner of the Shale gas. ${ }^{90}{ }^{91}$ This further analysis

81. Cabot Oil \& Gas Corp. v. Jordan, 698 F. Supp. 2d 474, 477 (M.D. Pa. 2010).

82. Julia, 2010 U.S. Dist. LEXIS 45821, at *9; Puza v. Elexco Land Servs., Inc., No. 3:09-CV-589, 2010 U.S. Dist. LEXIS 43346, at*9 (M.D. Pa. May 3, 2010).

83. Butler v. Charles Powers Estate, 29 A.3d 35, 37 (Pa. Super. Ct. 2011).

84. Id. at 41 (citing Silver v. Bush, 62 A. 832, 833 (Pa. 1906)).

85. Id. (citing Silver, 62 A. at 833).

86. Id. (citing Silver, 62 A. at 833).

87. Id. (citing Silver, 62 A. at 833).

88. Id. (citing Silver; Dunham and Shortt v. Kirkpatrick, 101 Pa. 36 (1882); Highland v. Commonwealth, 161 A.2d 390 (Pa. 1960)).

89. Id. at 43 .

90. Id.

91. In the similar case of PAPCO, Inc. v. United States, _ F. Supp. 2d _ , No. 08-253, $2011 \mathrm{WL}$ 3844120, at *14 (Aug. 30, 2011 W.D. Pa.), the Western District of Pennsylvania analyzed whether "a broad mineral reservation that extended to 'all the oil, natural gas, glass sand and minerals of every kind and 
will be illuminating, as due to the procedural posture of the case the Superior Court of Pennsylvania has, in actuality, simply returned the matter to the trial court for further proceedings.

\section{B. Lease Termination Claims}

Another area where the Pennsylvania courts have became involved, deals with issues of who owns the right to explore and produce. Two cases from the same federal court construing the same lease language reached opposite conclusions as to who owned the right to explore for and produce native natural gas in formations above and below a natural gas storage field. ${ }^{92}$ The leases in both cases granted the lessee the right to produce and store natural gas and provided that their term would continue so long as gas was stored or produced. ${ }^{93}$ The lessee had used the properties for decades for storage, but had never explored for native gas in any other zone. ${ }^{44}$ The lessor then entered into a top-lease with another producer and sought to invalidate the combination storage and production lease. ${ }^{95}$ In the first case, the federal court held that the original lessee had abandoned production rights under the lease and that it had breached an implied covenant to develop the property. ${ }^{96}$ In the second case, the same issue was decided, but with regard to many additional leases within two storage fields. In the second case, the federal court held that the lease meant what it said, i.e. the lease would remain in effect so long as the property was used for storage or production..$^{97}$ In the face of the parties' explicit

description whatsoever"' included sandstone extracted for commercial purposes. The PAPCO court also cited Silver and Highland, but, similar to the Superior Court of Pennsylvania in Butler, found that sandstone was not excluded from the mineral reservation. PAPCO, at *16. Additionally, in Hoffman $v$. Acrelormittal Pristine Resources, Inc., No. 11-CV-0322, 2011 WL 1791709, at *3 (May 10, 2011 W.D. Pa.), plaintiff argued that the term "all gas" in a deed "means only gas that is "contained within the sandstone strata underlying the subject land." Plaintiff supported this argument with the notion that because Marcellus shale gas was not an economically viable source for natural gas at the time of the deed (1928), the parties could not have intended to convey that gas. Id. The court, however, relying on the presence of the word "all," was not swayed by Plaintiff's argument. Id. at *4, *6. The Hoffman court also found that the Plaintiff had not adversely possessed the mineral interests, as there had been no "actual possession, meaning drilling and production[] of the minerals ...." Id. at *7.

92. See Penneco Pipeline Corp. v. Dominion Transmission, Inc., Nos. 05-49, 05-537, 2007 WL 1847391 (W.D. Pa. June 25, 2007); Jacobs v. CNG Transmission Corp., 332 F. Supp. 2d 759 (W.D. Pa. 2004).

93. $I d$.

94. Id.

95. Id.

96. Jacobs, 332 F. Supp. 2d at 796.

97. The Magistrate Judge's report and recommendation can be found at Penneco, $2007 \mathrm{WL}$ 
agreement, the doctrines of abandonment and implied covenant to develop had no application.

A number of cases have addressed fact specific issues regarding the continuation of leases. For example, in the Sylvester case, a federal court refused to invalidate a lease because the production had tendered the up-front payment 23 days late, holding that the breach was not material where the lease did not state that "time was of the essence" and the royalty owner had not given notice and an opportunity to cure. ${ }^{98}$ In another lease validity decision, the Pennsylvania Supreme Court agreed to hear a decision by the Superior Court and upheld the validity of a 1928 lease which provided that it remained in effect so long as gas was produced in "paying quantities." The court held that the test for "paying quantities" was a subjective test and that the producer's determination would govern so long as it was made in good faith and not solely for the purpose of holding the land for speculative purposes. ${ }^{99}$

In Hite v. Falcon Partners, the court addressed the payment of delay rentals to extend lease terms. ${ }^{100}$ There, defendant was assigned numerous leases, each with: one year terms, delay rentals of $\$ 2$ per acre, and no habendum clause. ${ }^{101}$ Defendant utilized this anachronistic lease structure to hold the lease by paying only the minimal delay rentals, and not drilling. ${ }^{102}$ When the plaintiffs received offers from other producers to drill on their land, they asked defendant, under the lease's right of renewal clause, to match the offers. ${ }^{103}$ When defendant failed to respond, plaintiffs terminated the lease and filed suit. ${ }^{104}$ In affirming the Court of Common Pleas grant of summary judgment for the plaintiffs, the Pennsylvania Superior Court cited the lower court in stating that leases are not to be "construed to create a perpetual term unless the intention is expressed in clear and unequivocal terms." 105 The court reasoned that finding otherwise would be contrary to precedent, at odds with the parties' presumed intent, and at odds with delay rentals as a way of

1847391, at*3-26. The report was adopted by the district court, $i d$. at *3, and affirmed by the Third Circuit, 300 F. App’x 186, 187 (3d Cir. 2008). See also Williams \& Meyers, supra note 5, § 835.5.

98. Sylvester v. Sw. Energy Prod. Co., No. 3:CV-09-1653, 2009 WL 3633835, at*8 (M.D. Pa. Nov. 2, 2009).

99. T.W. Phillips Gas \& Oil Co. v. Jedlicka, 964 A.2d 13, 18 (Pa. Super. Ct. 2008), appeal granted, 978 A.2d 347 (Pa. 2009).

100. Hite v. Falcon Partners, No. 197 WDA 2010, 2011 WL 9632 (Pa. Super. Jan. 4, 2011).

101. Id. at $* 1$.

102. See id.

103. Id.

104. $I d$.

105. Id. at 4 . 
bringing about the development of minerals. ${ }^{106}$ Although relying on this case is not as clear cut as the use of a habendum clause to establish a primary term in which drilling must commence, it does seem that the Pennsylvania courts will now be reading a habendum clause into those few leases which do not contain them.

In Gates v. Exco Resources (PA), Inc., the court addressed a number of conflicts between a lessor, whose land was used for pasture, and a developerlessee. ${ }^{107}$ In addressing yet another royalty issue, the court held that when a lease calls for royalties to be paid only "for the gas marketed and used off the premises," a lessee who uses gas to operate a compressor on the site need not pay royalties on that gas. ${ }^{108}$ Additionally, the court held that when a lease states its purpose as for both drilling and "conducting such secondary or tertiary operations as may be required ... and ... placing tanks, equipment, roads and structures thereon," the lessor need not be compensated for land occupied by a meter station. ${ }^{109}$ Finally, the court found that when the lessee contracted to return the property to as near normal condition as possible, that duty is not abrogated by the fact that the loss of value which occurred was typical of the kind of loss inflicted by gas production operations. ${ }^{110}$

Lastly, in Smith v. Ridge, LP, the court dealt with a lease that allowed the lessee to convert the lease from a development lease to a storage lease by paying the lessor the estimated value of the remaining recoverable gas, as well as delay rentals for the time period the property was used for storage. ${ }^{111}$ Two months after purchasing the lease, defendant made an attempt to convert the lease by paying plaintiff. ${ }^{12}$ Although plaintiff refused payment, defendant still filed a conversion notice with the Recorder of Deeds. ${ }^{113}$ After another attempt to pay plaintiff failed, plaintiff finally accepted payment on defendant's third offer. ${ }^{114}$ However, plaintiff then requested a determination that a de facto taking of its property had occurred under the Pennsylvania Eminent Domain Code. ${ }^{115}$ In ruling on plaintiff's argument that the lease was no longer valid because production had ceased before the attempted conversion, the court

106. Id. at 5 .

107. Gates v. Exco Res. (PA), Inc., No. 07-104 E, 2010 WL 1416740 (W.D. Pa. Apr. 8, 2010).

108. Id. at $* 11$.

109. Id. at $* 12$.

110. $I d$.

111. Smith v. Ridge, LP, No. 3:09-268, 2010 WL 3905071 (W.D. Pa. Sept. 29, 2010).

112. Id. at *1.

113. $I d$.

114. $I d$.

115. $I d$. at $* 2$. 
found that the term "cessation of production" in the lease was ambiguous, and thus summary judgment was not proper on that issue. ${ }^{116}$ The court came to the same conclusion with regard to plaintiff's arguments regarding the "shut-in" provision, and the lack of "delay payments." 117 Finally, the court refused to issue summary judgment on the issue of whether or not notice was required to be given to plaintiff in order to convert the lease, labeling this as a "disputed issue of fact ... material to this case," 118 since defendant contested plaintiff's interpretation of the issue.

As the Marcellus Shale production develops, an increasing number of actions over who owns the right to explore for and produce gas can be expected.

\section{Surface Owner Claims}

Increased drilling has also brought a predictable increase in disputes arising between surface owners and producers. In these situations, the surface of a property has been severed from the mineral estate and the surface owner no longer owns any interest in the minerals beneath his land. This means that while a well or other appurtenant facility may be constructed on the surface owners' property, the surface owner does not share in the royalties from production. Although to date, there have been relatively fewer cases in the Marcellus Shale region involving disputes between surface owners and production companies as compared to lease disputes, courts in the region are increasingly faced with a variety of issues surrounding the production company's use of the surface, including the construction of access roads, the cutting of timber, damage to crops, use of surface water, etc.

Nine states, including West Virginia, have enacted some form of a surface damages law that serves as the statutory determinant, in lieu of the common law implied easement system for when the mineral owner or lessee must compensate the surface owner for the use of the surface. ${ }^{119}$ Pennsylvania, however, has yet to adopt such a statute. Therefore, in surface owner dispute situations, the courts are faced with the question of what constitutes "reasonable use" of the surface.

116. Id. at *4-5 (citing the Third Circuit's definition of unambiguous as "reasonably capable of only one construction").

117. Id. at $* 5$.

118. Id.

119. Williams \& MeYers, supra note 5, at $\S 218$. 
Since the late 1800 s, courts in Pennsylvania have recognized that owners and lessees of mineral rights have the right to use so much of the surface as is "reasonably necessary" in order to access what they own. ${ }^{120}$ This notion of the reasonableness of the subsurface owner or lessee's use of the surface is still the standard today. ${ }^{121}$ Until recently, a 1980 landmark Pennsylvania federal district court decision, United States v. Minard Run Oil Co., was the only case to really address these issues. In that case, the court harkened back to an 1893 Pennsylvania Supreme Court case to state that:

\begin{abstract}
It is not surprising that the Supreme Court at that time enunciated the rule which has been followed ever since in Pennsylvania, that the parties must each exercise due regard for the rights of the other, that while the owner of the mineral rights has unquestioned right to enter upon the property for the purpose of access and extracting his minerals, he nevertheless must exercise such rights with a recognition of surface rights and taking appropriate action to prevent unnecessary disturbance to the owner of the surface. ${ }^{122}$
\end{abstract}

In 2009, the federal district court for the Western District of Pennsylvania addressed a related issue in a subsequent Minard Run case. ${ }^{123}$ From 1980 until 2008, the United States Forest Service (USFS), in accordance with the 1980 Minard Run settlement agreement, reviewed requests by oil and gas drilling companies to conduct drilling operations in the Allegheny National Forest (ANF). ${ }^{124}$ Upon approval of those requests, it issued Notices to Proceed. ${ }^{125} \mathrm{In}$ 2007, the USFS determined that the federal National Environmental Policy Act (NEPA) applied to Notices to Proceed, which led to lawsuits by environmental interest groups demanding that the USFS require Environmental Impact Statements for all requests to conduct drilling in the ANF. ${ }^{126}$ The USFS and environmental interest groups entered into a settlement agreement in 2009 whereby the USFS agreed to analyze all future drilling proposals on split mineral estates in the ANF in accordance with NEPA. ${ }^{127}$ The agreement provided, inter alia, that the USFS environmental impact

120. See, e.g., Chartiers Block Coal Co. v. Mellon, 25 A. 597 (Pa. 1893); Oberly v. H.C. Frick Coke Co., 104 A. 864 (Pa. 1918).

121. United States v. Minard Run Oil Co., No. 80-129, 1980 U.S. Dist. LEXIS 9570, at*13-14 (W.D. Pa. Dec. 16, 1980).

122. Id. (citing Chartiers, 25 A. at 598).

123. Minard Run Oil Co. v. United States Forest Serv., No. 09-125, 2009 U.S. Dist. LEXIS 116520 (W.D. Pa. Dec. 15, 2009).

124. Id. at *20-21.

125. Id. at $* 21,66$.

126. $I d$. at $* 29-30$.

127. Id. at *31-32. 
analyses conducted pursuant to NEPA, each of which was estimated to take between one to five years to process, would then serve as a prerequisite to issuing the Notices to Proceed to oil and gas drilling companies. ${ }^{128}$

The natural gas industry, led by the Pennsylvania Oil and Gas Association, filed suit seeking an injunction both to stop the new practice and to return to the previous method. ${ }^{129}$ In analyzing the case, the court looked at the prior case law to determine that the mineral rights were subject to limited review by the USFS. ${ }^{130}$ The court also held that USFS regulation of oil and gas drilling was further limited as part of the 1980 Minard Run Settlement Agreement, which was later codified as part of the Energy Policy Act of 1992. ${ }^{131}$ None of the requirements imposed on the USFS pursuant to the act involved a NEPA-based environmental impact analysis of the various requests to conduct oil and gas drilling. Instead, the court found that the NEPA requirements were triggered only by a proposal for major federal action and the USFS review of the drilling requests did not constitute such action. ${ }^{132}$ In addition, the court found that the USFS did not possess the regulatory authority it claimed under the Weeks Act of 1911 with regard to the processing of oil and gas drilling proposals. ${ }^{133}$ On these grounds, the court granted the preliminary injunction and enjoined the USFS from requiring the preparation of a NEPA document as a precondition to the exercise of private oil and gas rights in the ANF. ${ }^{134}$ It also preliminarily enjoined the USFSimposed forest-wide drilling ban in the ANF and ordered the USFS to comply with the 1980 Minard Run Settlement Agreement requirements. ${ }^{135}$

Recently, the Third Circuit Court of Appeals "affirm[ed] in all respects the District Court's thorough, well-reasoned opinion" in Minard Run. ${ }^{136}$ The Third Circuit confirmed that in Pennsylvania, the mineral estate was the dominant estate, and was to be granted whatever surface use was reasonably necessary for extraction. ${ }^{137}$ The court also cited Belden \& Blake for the idea that surface owners cannot permissibly "impose conditions restraining those

128. Id. at $* 37$.

129. Id. at $* 71$.

130. Id. at *63-92.

131. Id. at *20; see 30 U.S.C. § 226(o) (1992).

132. Minard Run Oil Co., 2009 U.S. Dist LEXIS 116520, at*67-68.

133. Id. at $* 85$.

134. Id. at $* 92-93$.

135. Id. at $* 94$.

136. Minard Run Oil Co. v. U.S. Forest Service, __ F.3d _ _ Nos. 10-1265, 10-2332, 2011 WL 4389220, at*1 (3d Cir. Sept. 20, 2011).

137. Id. at *2 (citing Belden \& Blake Corp. v. Commonwealth, 969 A.2d 528, 532 (Pa. 2009)). 
exercising their rights to the subsurface."138 Ultimately, the Third Circuit agreed with the District Court that the USFS did not have the "broad authority" it claimed to wield over mineral owners' access to the surface. ${ }^{139}$

In a state court case also decided in 2009, Belden \& Blake $v$. Commonwealth of Pennsylvania, the Pennsylvania Supreme Court held in favor of the mineral owner where the surface owner, the Pennsylvania Department of Conservation and Natural Resources (DCNR), attempted to impose various conditions on the mineral owner before commencing drilling operations. ${ }^{140}$ In this case, Belden \& Blake held the rights to oil and gas for certain parcels of land beneath Oil Creek State Park. ${ }^{141}$ The producer gave notice to DCNR of its intention to develop gas wells on the tracts, but DCNR responded by imposing conditions on the development including: (a) execution of a right-of-way/coordination agreement; (b) posting of a $\$ 10,000$ performance bond for each well; and (c) payment of $\$ 74,885$ in fees for removal of timber. Rather than agreeing to these conditions, Belden \& Blake filed suit seeking to enjoin DCNR from interfering with its use of the surface estate along with a declaration that it had an implied easement over the surface. ${ }^{142}$

The court, relying on the Chartiers case, held that the exercise of a subsurface owner's rights must be reasonable and that "Belden \& Blake facially fulfilled its obligation to do so." 143 The court confirmed the trial court's ruling that DCNR may not unilaterally impose additional conditions on Belden \& Blake's exercise of its right to access its mineral interests. ${ }^{144}$ It also recognized that "a [subsurface] property owner's interests and rights cannot be lessened, nor their reasonable exercise impaired without just compensation, simply because a government agency with a statutory mandate comes to own the surface." 145 Although the court noted that DCNR has a duty to maintain and preserve state parks, it underscored the fact that the surface owner has the burden to challenge the subsurface owner's reasonable exercise of its rights, not the reverse. ${ }^{146}$

138. Id. at *11 (citing Belden \& Blake, 969 A.2d at 532).

139. Id. at $* 12$.

140. Belden \& Blake, 969 A.2d 528, 531-32 (Pa. 2009).

141. Id. at 529 .

142. Id.

143. Id. at 532.

144. Id. at 533 .

145. Id.

146. Id. at 532 . 
As mentioned above, to date, there have been relatively few cases dealing with disputes between surface owners and producers, but given the landscape of the state, with so many severed surface and mineral estates, and the increase in production that is planned to fully develop the Marcellus, an increase in these disputes seems inevitable.

\section{WATER LITIGATION AND OTHER ENVIRONMENTAL CLAIMS}

New areas in which the courts are beginning to weigh in on in Pennsylvania are environmental issues related to development of the Marcellus. To date, two recent cases dealing with strict liability claims alleging that hydrofracturing is an abnormally dangerous activity have survived motions to dismiss in the Pennsylvania Federal Courts. In Fiorentino v. Cabot Oil \& Gas Corp. ${ }^{147}$ and Berish v. Southwestern Energy Production Co. ${ }^{148}$ the plaintiffs each claimed that they were injured, both physically (past and future health problems) and economically (decrease in property value), by hydrofracturing chemicals that leached into the groundwater near to their properties. Both opinions determined that the plaintiffs sufficiently pleaded a cause of action for strict liability based on an abnormally dangerous activity and refused to dismiss their claims without further discovery. ${ }^{149}$ The Berish court indicated, however, that the plaintiffs would be fighting an uphill battle to prove that hydrofracturing is abnormally dangerous. ${ }^{150}$ In particular, of the factors that Pennsylvania courts consider in deciding whether an activity is abnormally dangerous, the plaintiffs would likely have difficulty proving that: (1) hydrofracturing is "not a matter of common usage"; (2) hydrofracturing is "inappropriate to the place where it is carried on"; and (3) the "value [of hydrofracturing] to the community is outweighed by its dangerous attributes." 151 When finally resolved, these cases will likely set important precedents for hydrofracturing claims in the Marcellus Shale going forward.

In addition to water cases, the Pennsylvania Commonwealth Court ruled in favor of the industry in a dispute with the coal industry, holding that a coal

147. No. 09-CV-2284 (M.D. Pa. Nov. 15, 2010).

148. No. 3:10-CV-1981 (M.D. Pa. Feb. 3, 2011).

149. See Fiorentino, No. 09-CV-2284 (M.D. Pa. Nov. 15, 2010); Berish, No. 3:10-CV-1981(M.D. Pa. Feb. 3, 2011).

150. Berish, No. 3:10-CV-1981 at *8-9.

151. Id. at *6-7. Other factors include: (1) the "existence of a high degree of risk of some harm to the person, land or chattels of others"; (2) the "likelihood that the harm that results from [hydrofracturing] will be great"; and (3) the "inability to eliminate the risk by the exercise of reasonable care." 
company that had "projected" a coal mine but had not yet started operating the mine had no standing to challenge permits issued for a well. ${ }^{152}$

\section{ZONING DISPUTES}

One final area of law that is being brought to the courts in Pennsylvania is the issue of the ability of local governments to regulate exploration and production companies. In 2009, the Pennsylvania Supreme Court held that local governments could exercise their traditional zoning powers to regulate certain aspects of drilling (such as the location of wells) ${ }^{153}$ but that attempted regulation of oil and gas drilling relating to permitting, bonding, environmental issues, site restoration, and plugging of wells was preempted by the state's regulation of the industry. ${ }^{154}$ In 2010 , the Pennsylvania Commonwealth Court sided with the local government and held the county's zoning regulations overlapped state regulation but did not cross the line because the regulations did not constitute a "comprehensive regulatory scheme." $" 155$

\section{OTHER MARCELLUS RELATED LITIGATION}

Pennsylvania courts have also made recent decisions regarding the administrative aspects of oil and gas leases. In Chesapeake Appalachia, L.L.C. v. Golden, the Wayne County Recorder of Deeds had rejected a number of documents presented by the plaintiff for filing. ${ }^{156}$ The Court began by finding that the Recorder of Deeds' functions were not purely ministerial in that the Recorder of Deeds could not accept documents that did not comport with the law without violating its own statutory obligations. ${ }^{157}$ Therefore, the Recorder of Deeds must determine whether or not instruments are properly acknowledged before recording them. ${ }^{158}$ This, however, along with a review for a statement of value, is the only assessment the Recorder of Deeds can

152. Found. Coal Res. Corp. v. Dep't of Envtl. Prot., 993 A.2d 1277 (Pa. Commw. Ct. 2010).

153. Huntley \& Huntley, Inc. v. Borough Council of Oakmont, 964 A.2d 855 (Pa. 2009).

154. Range Res. v. Salem Twp., 964 A.2d 869 (Pa. 2009).

155. Penneco Oil Co., Inc. v. County of Fayette, No. 18 C.D. 2010, 2010 WL 2853639 (Pa. Commw. Ct. 2010).

156. Chesapeake Appalachia, L.L.C. v. Golden, No. 479-Civil-2010, id. at 2 (Ct. Cmn. Pls. of Wayne County Nov. 24, 2010)

157. Id. at 4-5.

158. Id. at 6 . 
validly make. ${ }^{159}$ In a later Order, the court in Golden gave perhaps the most important finding of that case, regarding "whether or not the Recorder has a statutory duty to record assignments of multiple oil and gas leases (referred to as blanket assignments)." 160 And, the court did so find, stating that "the Recorder is not ... authorized" to refuse to file blanket assignment documents. ${ }^{161}$ The court's decision on blanket assignments is currently on appeal to the Pennsylvania Commonwealth Court.

\section{CONCLUSION}

Now is an exciting time to be involved in the litigation of disputes regarding oil and gas production and development. Though there are many sources of guidance for how disputes will be resolved by the courts, both from the historic case law in the state and the significant jurisprudence in other jurisdictions, there are also many open legal questions that will undoubtedly be resolved as the development of the Marcellus Shale matures.

159. Id. at $8,11-12$.

160. Chesapeake Appalachia, L.L.C. v. Golden, No. 479-Civil-2010, id. at 1 (Ct. Cmn. Pls. of Wayne County Apr. 21, 2011).

161. Id. at 2. 